Ónya Balázs

\title{
Két érv az igazság definiálhatatlansága mellett ${ }^{1}$
}

\section{Bevezetés}

Vannak, akik szerint a filozófia egyik célja az, hogy pontosan definiáljon vagy legalább részben tisztázzon bizonyos fogalmakat, különös tekintettel azokra, amelyek alapvető jelentősége és nélkülözhetetlensége aligha kérdőjelezhető meg. Többek között ilyen fogalom a hétköznapi, tudományos és filozófiai diskurzusokban egyaránt rendszeresen használt igazság fogalma is. Ám az igazságfogalom alapvető jelentősége ellenére - vagy talán éppen annak köszönhetően - még nem sikerült kielégítő választ adni az igazságfogalmunkkal kapcsolatos legégetőbb kérdésekre: mit értünk egész pontosan azon, hogy valami igaz; miféle dolgokról mondhatjuk egyáltalán azt, hogy igazak; minek köszönhetően igaz az, ami igaz; és így tovább.

Tanulmányomban természetesen nem e kérdések kimerítő megválaszolására vállalkozom, célom abban áll, hogy az igazság természetére vonatkozó álláspontok egyike, nevezetesen az igazsággal kapcsolatos primtivizmus (továbbiakban: alethikus primitivizmus) tarthatóságát két érv alaposabb vizsgálatával védelmembe vegyem.

Az alethikus primitivizmusnak két fó állítása van. Egyrészt az, hogy az igazság fogalmát nem lehet definiálni, másrészt hogy az igazság fogalmát, annak definiálhatatlansága ellenére, fel lehet használni más, definiálhatónak vélt és az igazságénál elméleti szempontból bonyolultabbnak tartott fogalmak definiálására, magyarázatára. ${ }^{2}$ Ilyen fogalmak például a jelentés, a tudás vagy helyes következtetés fogalmai. Ennek részleteire a későbbiekben kitérek, most azért vezettem be az alethikus primitivizmus két fó állítását, hogy tisztázzam, elsősorban az első állítással foglalkozom, és kevésbé fogom érinteni más fogalmaknak az igazságfogalmat felhasználó definiálásának kérdését. Tehát mindössze arra kívánok rámutatni, hogy az igazság definiálhatatlanságának bizonyításához milyen filozófiai érveket mozgósíthatunk.

A dolgozatban először az alethikus primitivizmus egyik legelső képviselőjeként számontartott Gottlob Frege az igazság definiálhatatlansága mellett felhozott érvét rekonstruálom, miközben kísérletet teszek egy lehetséges ellenvetés megválaszolására.

1 Köszönettel tartozom témavezetőmnek, Kocsis Lászlónak, továbbá Pete Krisztiánnak, Tuboly Ádám Tamásnak és a két bírálómnak egyaránt. Megjegyzéseikkel és javításaikkal nagyban hozzájárultak, hogy a szöveg elnyerje jelenlegi formáját.

2 A fogalmi analízis részletes bemutatásához lásd: Strawson 1992; Jackson 2000; Márton 2010, 43-56. 
Majd a primitivista nézetek aranykorának tekinthető, XX. század eleji filozófia egy másik prominens alakjának, George Edward Moore-nak a jó fogalmával kapcsolatos primitivizmusát vizsgálom meg: elsősorban az érdekel, hogy Moore-nak a jó definiálhatatlansága mellett szóló nyitott kérdés argumentuma alkalmazható-e az alethikus primitivizmus első - negatív - állításának alátámasztására.

\section{Az igazságelméletekről általában}

Az igazságra gondolhatunk úgy mint fogalomra, ${ }^{3}$ amellyel rendelkezünk, például, amikor valamit igaznak tartunk; továbbá úgy is mint tulajdonságra ${ }^{4}$ amivel bizonyos típusú dolgok, vagyis az úgynevezett igazsághordozók - propoziciók, kijelentések, állitások, vélekedések, kijelentö mondatok - rendelkeznek. Ez utóbbi esetben azt vizsgáljuk, hogy milyen ennek a tulajdonságnak a természete, illetve az imént említésre került jelöltek közül, egész pontosan melyik típusú igazsághordozó rendelkezhet (alapvetően) ezzel a tulajdonsággal. ${ }^{5} \mathrm{Az}$ igazságelméletekben alapvetően két fö irányzatot különböztethetünk meg: a szubsztantivista és deflácionista megközelítést.

A szubsztantivisták úgy tartják, hogy az igazság egy szubsztantív, definiálható fogalom és tulajdonság, mert feltételezik, hogy van olyan fogalom vagy fogalmak halmaza (ilyen lenne a „korrespondencia”, a „tény”, a „koherencia”, vagy akár a „hasznosság” fogalmai), amellyel képesek vagyunk tisztázni, hogy mit értünk azon, hogy valami igaz, illetve képesek vagyunk megadni a szükséges és elégséges feltételeit annak, hogy valami rendelkezik az igazság tulajdonságával. ${ }^{6}$

A három legnépszerủbb szubsztantivista igazságelmélet definíciós kísérletei:

(KorrT) p igaz akkor és csak akkor, ha p megfelel a tényeknek.

(KohT) p igaz akkor és csak akkor, ha p egy koherens propozicióhalmaz eleme.

(PragT) p igaz akkor és csak akkor, ha $p$ olyan, hogy hasznos hinni.

A szubsztantivistákkal szemben a deflácionista igazságelméletek szerint az igazság szerepe kimerül bizonyos expresszív funkciók betöltésében. Egyrészt tagadják, hogy az igazságnak elméletileg jelentős szerepe van akár a hétköznapi, akár a tudományos dis-

3 Az igazságra primitiv fogalomként tekint Davidson 1996, Sosa 2001, Patterson 2010.

4 Az igazságra primitiv tulajdonságként tekint Moore 1993a, Russell 1904.

5 Ezzel a két szemponttal még nem fedtük le az összes lehetőséget. Frege például logikai tárgyként gondol az igazságra (és hamisságra egyaránt). Fregével a 3. szakaszban foglalkozom részletesebben. Hasonló felosztást használ Asay 2013, 11-17 és Kocsis 2018, 15-25.

6 A szubsztantivista igazságelméleteket és azok problémáit részletesen bemutatja Kocsis 2018, 34-89. 
kurzusokban, másrészt tagadják, hogy az igazság definiálható, analizálható. Ezzel szemben azt gondolják, hogy az igazság alapvető, egyszerü fogalom, amelyet nem lehet magyarázni más, alapvetőbb fogalmakkal, és az igazság által sem lehet megmagyarázni egyéb fogalmakat. Egyetértenek abban, hogy az igazság túlértékelt, inflált fogalom, és a szó eredeti értelmében egyáltalán nem fogható fel tulajdonságnak, éppen ezért az igazság filozófiai problémáját mondvacsináltnak tekintik és az igazságfogalom deflálására tesznek kísérletet. ${ }^{7}$ Elméletük kidolgozásában kardinális szerepe van az úgynevezett (T)-bikondicionálisoknak vagy (T)-mondatoknak, amelynek a formája a következő:

(T) A p propozíció igaz akkor és csak akkor, ha $p$.

A deflácionisták szerint a (T)-sémával mindent el lehet mondani az igazságról, nincs szükség más fogalomra. A séma behelyettesített esetei nem nyújtják az igazság definícióját, legalábbis nem olyan explicit módon, ahogy azt a szubsztantivisták teszik, ugyanakkor a (T)-séma előnye, hogy behelyettesített esetei a priori tudhatók és szükségszerüen igazak.

Az alethikus primitivizmus képviselői az imént vázolt két nézet egyikével sem tudnak teljes mértékig azonosulni, egy harmadik álláspontot képviselnek. Eszerint (1) az igazságot nem lehet egyéb, alapvetőbb fogalmakkal világosabbá tenni; (2) az igazság fogalmával számos másik, elméleti szempontból fontos fogalom definiálható, illetve (3) az igazság fontos elméleti szerepet tölt be, nagy magyarázóerővel bír, valamint a hétköznapi diskurzusban is teljesen legitim módon használható. Az igazsággal kapcsolatos primitivizmust éppen az különbözteti meg a deflácionizmustól, hogy az előbbiek szerint az igazság fogalmával lehet magyarázni más, az igazságnál bonyolultabb fogalmakat. A teljesség igénye nélkül említek pár példát arra, hogy mely fogalmaink definiálására lehet alkalmas az igazság: igazolás (akkor vagyunk igazoltak egy hitünkkel kapcsolatban, ha jó indokok szólnak amellett, hogy hitünk tárgya igaz); logikai következtetés (egy logikai következtetés konklúziója szükségszerűen igaz, ha a konklúzióhoz vezető premisszák igazak); tudás (igazolt igaz vélekedés); jelentés (akkor tudjuk egy mondat jelentését, ha tudjuk, hogy mikor igaz).

Ebben a tanulmányban a deflácionizmus és primitivizmus megkülönböztetése nem lesz különösebben releváns, ugyanis nem amellett kívánok érvelni, hogy akár Frege, akár Moore érvei rekonstruálhatók úgy, hogy arra következtessünk belőlük, hogy az igazsággal definiálhatók más fogalmak, hanem alapvetően arra teszek kísérletet, hogy érveiket az igazság definiálhatatlansága melletti meggyőző érvekként mutassam be. ${ }^{8}$

7 A deflácionista elmélet részletes ismertetéséhez magyarul lásd Kocsis 2018, 89-129.

8 Ehhez lásd: Asay 2013, 2014. Asay alaposan vizsgálja a primitivizmus második állításának részleteit, nevezetesen azt, hogy mely fogalmak definiálhatók az igazság segítségével. 


\section{Frege érve az igazság definiálhatatlansága mellett}

Az igazság definiálhatalansága melletti egyik, ha nem a legismertebb érvet Frege a következőképp fogalmazta meg:

Nem lehet esetleg megállapítani az igazság fennállását, ha bizonyos szempontból megegyezés van? De milyen szempontból? És mit kell tennünk annak eldöntéséhez, hogy valami igaz-e? Azt kellene megvizsgálnunk, igaz-e, hogy - mondjuk egy képzet és egy valós dolog - az illető szempontból megegyeznek. Ezzel újra ugyanolyan jellegű kérdés előtt állnánk, és az egész játékot újrakezdhetnénk. Ezzel meghiúsul az a kísérlet, hogy az igazságot úgy határozzuk meg, mint megegyezést. És igy hiúsul meg az igazság definiálására tett minden más kisérlet is. Egy definícióban ugyanis bizonyos ismertetőjegyeket adunk meg. Ha a definíciót alkalmazni akarjuk egy különös esetre, mindig azt kell megvizsgálnunk, igaz-e, hogy ezek az ismertetőjegyek megvannak. Így mindig körben forognánk. Ezek szerint valószínű, hogy az „igaz” szó tartalma egészen sajátos és definiálhatatlan. ${ }^{9}$

Frege ezt az érvet alapvetően az igazság korrespondenciaelméletével szemben fogalmazta meg, azonban az összes olyan szubsztantivista igazságelmélettel szemben is érvényes, amelyek kísérletet tesznek az igazság definiálására. Az érv rekonstruálható végtelen regresszus formában, ${ }^{10}$ valamint körkörös érvként is. ${ }^{11} \mathrm{~A}$ következőkben igyekszem úgy kibontani az érvet, hogy az elsőre nem teljesen világos, szubsztantivista definíciós kísérleteket kikezdő érv jobban kirajzolódjon. ${ }^{12}$

Mindenekelőtt tételezzük fel, hogy az igazság definiálható egy (SzubT) formájú bikondicionális segítségével, és azt is tegyük fel, hogy az igazsághordozók fregei propozíciók. Ebben az esetben így néz ki a bikondicionálisunk:

(SzubT) A p propozíció igaz akkor és csak akkor, ha $p F$.

(1) Ha az igazság definíció szerint azonos $F$-fel, akkor minden igaz propozíciónak rendelkeznie kell az $F$ tulajdonsággal.

(2) Ha azt állítjuk/véljük/gondoljuk, hogy egy adott partikuláris propozíció, vagyis $p$ rendelkezik az $F$ tulajdonsággal, akkor egyben azt is állítjuk/véljük/gondoljuk, hogy az a propozíció, hogy $p F$ igaz.

9 Frege 2000, 194. (Saját kiemelés.)

10 Dummett 1973, 442-471.

11 Stepanians 2003, 331-345.

12 Az érv rekonstrukciójához alapot nyújtott Soames 1999, 25 és Kocsis 2018, 79. 
(3) Továbbra is tegyük fel, hogy az igazság definiálható úgy, mint $F$, vagyis, ha $p$ igaz, akkor rendelkezik az $F$ tulajdonsággal.

Ezek szerint, ha azt állítjuk/véljük/gondoljuk, hogy $p$ rendelkezik az $F$ tulajdonsággal, akkor két dolgot tehetünk, és ettől függően lesz az érv (K1) körkörösségi érv vagy (K2) végtelen regresszus érv.

(K1) Ahhoz, hogy kideríthessük, $p$ rendelkezik-e az $F$ tulajdonsággal, először azt kell tisztáznunk, hogy igaz-e az a propozíció, hogy $p F$. Ebben az esetben körben forgunk, hiszen pontosan azt szeretnénk megmagyarázni, hogy mit jelent egy propozícióra nézve, hogy igaz, ám azzal, hogy $p$ akkor és csak akkor igaz, ha $p F$, nem fogunk valódi magyarázatot kapni, ha mindenekelőtt azt kell tisztáznunk, hogy igaz-e, hogy $p$ rendelkezik az $F$ tulajdonsággal.

(K2) Ahhoz, hogy kideríthessük, $p$ rendelkezik-e az $F$ tulajdonsággal, először azt kell tisztáznunk, hogy igaz-e az a propozíció, hogy $p F$. Mivel az igazsággal rendelkezni nem más, mint az $F$-ség tulajdonságával rendelkezni, éppen ezért mindenekelőtt azt kell megvizsgálnunk, hogy az a propozíció, hogy $p F$ maga rendelkezik-e az $F$ tulajdonsággal, ezt azonban csak úgy tudjuk megtenni, ha megvizsgáljuk, hogy az a propozíció, hogy $(p F) F$ rendelkezik-e az $F$ tulajdonsággal, és így tovább a végtelenségig.

Frege érvének fenti változatából azt a következtetést vonhatjuk le, hogy az igazság azon fogalmaink egyike, amely definiálhatatlan, mert - attól függően ugyan, hogy melyik konklúziót fogadjuk el - az igazság definiálása során szükségszerủen a körkörösség vagy végtelen regresszus csapdájába esünk. Ugyanakkor bárki felvethetné a kérdést, hogy miért kellene elfogadnunk Frege premisszáit. Különösen a 2. premissza kapcsán támadhatnak kételyeink.

A kérdés az, hogy ha azt gondolom egy propozícióról, hogy az rendelkezik $F$ tulajdonsággal, akkor miért kellene egyúttal azt is gondolnom, hogy igaz, hogy a kérdéses propozíció rendelkezik az $F$ tulajdonsággal. Különösen akkor aggályos mindez, ha osztozunk a szubsztantivisták azon nézetében, miszerint létezik az igazságnál alapvetőbb fogalom, amelyet fel tudunk használni az igazság meghatározásához. A szubsztantivisták szerint - még egyszer - képesek vagyunk megmondani, hogy mi az az $F$ tulajdonság, amely közös minden igaz propozícióban, vagyis vannak olyan fogalmaink, amelyek segítségével tisztázni tudjuk, hogy mit jelent igaznak lenni. Mivel mi azt szeretnénk tudni, hogy mit jelent egy propozíció esetében, hogy az igaz, és ha igaznak lenni annyi, mint $F$ tulajdonsággal rendelkezni, akkor nem világos, hogy miért kellene még annak az 
igazságát is gondolnunk, hogy $p$ rendelkezik az $F$ tulajdonsággal, vagyis $p$ igaz. Tehát, ha Frege érvét először vesszük szemügyre, akkor joggal támadhatnának kételyeink, különösen a második premisszát illetően, ám ha számításba vesszük Fregének a második premisszát támogató tézisét, akkor ezek a kételyek megszűnhetnek, vagy legalábbis mérséklődhetnek. Ez a tézis az igazság mindenütt jelenvalóságát állítja, és Frege így ír róla:

Mindamellett azt kell gondolnunk, nem lehetséges felismerni egy dolog valamely tulajdonságát anélkül, hogy egyúttal igaznak ne találnánk azt a gondolatot, mely szerint a dolog rendelkezik az illető tulajdonsággal. Így egy dolog minden tulajdonságához kapcsolódik egy gondolat tulajdonsága, tudniillik az igazsága. Figyelemreméltó az is, hogy az „ibolyaszagot érzek” mondatnak ugyanaz a tartalma, mint az „igaz, hogy ibolyaszagot érzek" mondatnak. Úgy tűnik tehát, hogy a gondolathoz semmit sem teszünk hozzá azzal, hogy igazságot tulajdonítunk neki. ${ }^{13}$

Frege szerint, ha egy bizonyos dologgal kapcsolatban úgy gondolom, hiszem vagy állítom, hogy a kérdéses dolog, mondjuk a kutyám, rendelkezik a négylábúnak levés tulajdonságával, akkor ezt nem tudom gondolni, hinni vagy állítani anélkül, hogy a gondolatomat, a vélekedésemet, vagy a gondolatomat vagy vélekedésemet kifejező mondatokat igaznak ne tartanám. ${ }^{14}$ Továbbá Frege a fenti passzusban nem csupán azt állítja, hogy minden tulajdonságtulajdonítás együtt jár azzal, hogy igaznak találjuk a gondolatot, miszerint a kérdéses dolog rendelkezik a kérdéses tulajdonsággal, hanem azt is, hogy amikor igazságot tulajdonítunk egy gondolatnak, akkor valójában nem változtatjuk meg a gondolatot. Frege szerint tehát ami a mondatok jelentését, vagyis az általuk kifejezett propozíciós tartalmakat illeti „A kutyámnak négy lába van.” és az „Igaz, hogy a kutyámnak négy lába van.” mondatok között nincs különbség.

Meg kell jegyezni azonban, hogy még ha plauzibilisnek is tűnik Frege jelentésazonosság melletti állásfoglalása, valójában indokolatlanul erős elköteleződésnek tűnik, ugyanis a két mondat másról szól, vagy ha úgy tetszik, más tényt ír le: az első mondat a kutyáról szól, a második viszont a gondolatról, amit az első mondat kimondása során fejezünk ki. Ám akár elfogadjuk Frege álláspontját abban a kérdésben, hogy az „igaz, hogy" kifejezés valamely értelmes kijelentő mondat elé illesztése semmit nem változtat a kérdéses mondat jelentésén, akár nem fogadjuk el, az igazság mindenütt jelenvalósági

13 Frege 2000, 196.

14 Ahogy nem lehet valamit valamilyennek gondolni anélkül, hogy ne tartanánk igaznak a gondolatot, éppúgy nem lehet állítani anélkül, hogy az állítás tartalmát, vagyis azt, amit kimondunk az állítás során, ne tartanánk igaznak. Ugyanis ha egy állítástétel szükséges feltételének tartjuk az őszinteséget, akkor ha valaki kijelent egy mondatot anélkül, hogy hinne ezen mondat igazságában, nem beszélhetünk állításról. 
tézise ettől függetlenül tartható. Nem gondolhatom vagy hihetem azt, hogy a kutyámnak négy lába van, anélkül, hogy egyúttal ne gondolnám vagy hinném ezt is: igaz, hogy a kutyámnak négy lába van. Nem szükséges azt gondolnunk, hogy a két állítás azonos jelentéssel bír, elég elfogadnunk azt, hogy amikor hisszük, hogy $p$, akkor egyben igaznak is tartjuk $p$-t, márpedig az igazság mindenütt jelenvalóságának tézise pusztán ezt állítja. Ha viszont ilyen szoros logikai kapcsolat áll fenn egy fregei értelemben vett gondolat, ${ }^{15}$ avagy propozíció kimondása és a propozíció igazságának elismerése között, akkor nem ismerhetjük fel egy tárgy valamely $F$ tulajdonságát anélkül, hogy ne gondolnánk, hogy igaz az, hogy az adott tárgy rendelkezik az $F$ tulajdonsággal. Visszatérve tehát a második premissza elfogadásának problémájához: amikor egy szubsztantivista azt hiszi, hogy $p F$, akkor egyúttal azt is hiszi, hogy $p F$ igaz. Úgy tünik tehát, hogy - amenynyiben elfogadjuk Frege azon tézisét, hogy az igaznak tartás minden állításunkat vagy vélekedésünket kíséri - a (2) premissza elfogadhatónak és megalapozottnak tűnik. Ahhoz tehát, hogy Frege körkörös/regresszus érvét cáfolni tudjuk, ahhoz elöször az igazság mindenütt jelenvalóságának tézisét kell megcáfolnunk.

Frege tézise analógiát mutat Immanuel Kant azon állításával, miszerint a létezés nem valódi tulajdonság, hanem előfeltétele annak, hogy egyáltalán bármilyen tulajdonságot tulajdoníthassunk egy bizonyos dolognak. „A lét nyilvánvalóan nem reális predikátum, azaz nem olyasvalaminek a fogalma, ami hozzáadódhatnék a dolog fogalmához." ${ }^{16}$ Hasonlót állít Frege az igazságról, mégpedig azt, hogy az igaznak tartás - még ha nem is előfeltétele egy állításnak - szimultán van jelen a mondat állításával anélkül, hogy bármilyen plusz információt hozzáadna a mondat jelentéséhez. Ahogy Jamin Asay írja:

Kant alapján: nincs különbség egy olyan istenfogalom között, ami (a) mindentudó, mindenható és legfóbb jó, illetve egy olyan istenfogalom között, ami (b) mindentudó, mindenható, legfőbb jó és létező. Ennek eredményeképp semmi sem kényszeríthet minket arra, hogy a (b) fogalom alá tartozó dolgokat tökéletesebbnek tartsuk, mint az (a) fogalom alá tartozó dolgokat, amiből arra következtethetnénk, hogy az elképzelhető legtökéletesebb dolognak létezni kell. ${ }^{17}$

Ahogy a tökéletes lényként felfogott Isten fogalmához nem tesz hozzá semmit létezésének említése, éppúgy nem tesz hozzá semmit egy vélt vagy állított propozícióhoz annak említése, hogy a kérdéses propozíció igaz.

15 Frege terminológiájában a „gondolat” szó megfeleltethető annak, amit ma propozíciónak hívunk.

16 Kant 2009, 485.

17 Asay 2014, 508-9. 
Felmerülhet a kérdés, hogy vajon Frege az igazsággal kapcsolatos primitivizmus vagy inkább az igazsággal kapcsolatos deflácionizmus alapjait dolgozta-e ki. Bár - ahogy azt korábban is említettem - nem célom, hogy számot adjak az igazság magyarázati szerepének jelentőségéről, a továbbiakban kitérek arra, hogy Frege egyéb elköteleződéseit figyelembe véve milyen szerepet tulajdonított az igazságnak. A Fregére sütött deflácionizmus bélyegét elkerülendő a következőkben amellett érvelek, hogy Frege az igazság fogalmával magyarázhatónak tartott egyéb fogalmakat, amelynek következtében nem állíthatjuk jogosan Fregéről, hogy a deflácionizmust képviselte volna.

Megkísérelhetnénk, hogy a gondolatnak az Igazhoz való viszonyát ne mint a jelentés és a jelölet, hanem mint az alany és az állítmány viszonyát fogjuk fel. Hiszen azt is mondhatjuk: „Az a gondolat, hogy az 5 törzsszám, igaz.” Pontosabban szemügyre véve, észreveszszük azonban, hogy ezzel voltaképpen nem mondtunk többet, mint a következő egyszerű mondattal: „Az 5 törzsszám.” Az igazság állítása mindkét esetben a kijelentő mondat formájában rejlik, és ott, ahol e forma nem bír szokásos erejével, például egy színész előadásában a színpadon, az olyan mondat, mint ,az a gondolat, hogy az 5 törzsszám, igaz”, éppen úgy csak egy gondolatot tartalmaz, éspedig ugyanazt a gondolatot, mint „az 5 törzsszám” egyszerủ mondat. Ebből látható, hogy a gondolat viszonya az Igazhoz mégsem hasonlítható az alanynak az állítmányhoz való viszonyához. Az alany és az állítmány (logikai értelemben véve) a gondolat részei; a megismerés ugyanazon szintjéhez tartoznak. Alany és állítmány összekapcsolásával mindig egy gondolathoz jutunk, de sohasem juthatunk el a jelentéstöl annak jelöletéhez, a gondolattól annak igazságértékéhez. ${ }^{18}$

Az idézett szövegből kiderül, hogy egy gondolat viszonyát az igazsághoz, a gondolatot kifejező mondat értelme és a gondolatot kifejező mondat referenciájának viszonyában ragadhatjuk meg, mégpedig úgy, hogy ennek megragadása egyirányú: az értelem/ jelentés határozza meg a referenciát, nem pedig forditva. Egy kijelentés értelme/jelentése a kijelentés által referált tárgy meghatározására szolgál. Például az „Alkonycsillag” és a „Hajnalcsillag” két különböző jelentésủ szó, ezért másképp referálnak a Vénusz bolygóra, annak ellenére, hogy mindkettő ugyanarra a tárgyra (a Vénuszra) referál. Azonban az egyik úgy referál rá, mint „az a csillag, amely legelsőként tűnik fel az esti égbolton”, a másik pedig úgy, mint „az a csillag, amely a legtovább látható a hajnali égbolton”.

Mivel Fregénél minden kijelentő mondat vagy az Igazra, vagy a Hamisra referál, és figyelembe vesszük azt is, hogy a mondat értelmétől/jelentésétől függően különböző módokon referálhatnak a mondatok valamelyik igazságértékre, akkor ebből arra lehet következtetni, hogy Frege az elsők között védelmezte azt, ami manapság a jelentés igazságfeltétel-elméletének neveznek. Eszerint akkor ismerjük egy mondat jelentését, ha is-

18 Frege 2000, 127. (Saját kiemelés.) 
merjük a mondat igazságfeltételeit, azaz tudjuk, hogy mely feltételek teljesülése esetén igaz a mondat. „A fü zöld.” mondat jelentését akkor ismerjük, ha tudjuk milyen körülmények között igaz: történetesen akkor, ha a fü zöld.

A mindenütt jelenvalósági tézist és az imént leírtakat figyelembe véve igazságelméleti szempontból releváns különbséget tehetünk állítások és más beszédaktusok között. Amennyiben állítok valamit, akkor egyben elköteleződöm amellett is, hogy a mondat igazságának feltételei teljesülnek. Példaként: akkor tudom, hogy az „A víz fagyáspontja $0{ }^{\circ} \mathrm{C}$." mondat mit jelent, ha tudom, hogy akkor és csak akkor referál az Igaz logikai tárgyra, amennyiben a világ tényleg úgy áll, hogy a víz fagyáspontja $0{ }^{\circ} \mathrm{C}$. Ebből következik, hogy a jelentés fogalma magyarázható az igazság fogalmával, s így kijelenthető, hogy Frege számol az igazság magyarázati szerepének jelentőségével. Ez alapján jó indokkal gondolhatjuk azt, hogy Frege nem csupán az igazság definiálhatatlansága mellett érvel, hanem egyben az alethikus primitivizmus előfutára is, amihez a legfontosabb elméleti lépésként kidolgozta az igazság definiálhatatlansága melletti első és azóta is egyik legjobbnak tűnő érvet. ${ }^{19}$

\section{4. Érvelhetünk-e Moore nyitott kérdés argumentumával az igazság definiálhatatlansága mellett?}

George Edward Moore az 1903-ban megjelent Principia Ethicaban az úgynevezett nyitott kérdés argumentum felhasználásával a jó(ság) primitív fogalomként való felfogása mellett érvelt. Moore szerint a jó természetéről a következők mondhatók el: a jó egyszerü, analizálhatatlan és redukálhatatlan morális fogalom, amelynek nem feleltethető meg semmilyen nem morális tulajdonság, valamint a jó megismerését egy kognitív képességünk, az intuíció biztosítja. Moore alapvetően az etikai naturalizmussal szemben dolgozta ki az érvét, amely szerint a jó redukálható egy természeti tulajdonságra, avagy azonosítható valamilyen természeti tulajdonsággal.

19 Fregenek van egy, az igazság korrespondenciaelméletével szemben megfogalmazott állítása, miszerint a korrespondenciaelméletben szereplő „megfelelés” fogalom meglehetősen homályos, ugyanis - Frege példájával élve - a kölni dóm képe és a leképezett kölni dóm között nem lehet teljes megfelelés, mert két különböző entitásról van szó. Márpedig, ha az igazság nem más, mint megfelelés, és teljes megfelelés nem lehetséges, akkor teljes igazság sem lehetséges - márpedig Frege szerint az igazság „nem tűri a többé vagy kevésbét”. (Frege 2000, 194) Ugyanez érvényes egy kijelentés és az általa leírt tény közötti megfelelési viszonyra: a kijelentés és a tény két különböző entitás, tehát nem állhat fent közöttük teljes megfelelés. Azonban ezzel jelen tanulmányban nem foglalkozom, tekintettel arra, hogy Frege ezen érve nem általában az igazság definiálhatatlansága mellett szól, hanem csupán a szubsztantív igazságelméletek egyikét érinti. Ehhez lásd Frege 2000, 193-194. 
Moore pár évvel a Principia Ethica megírása előtt az igazsággal kapcsolatban hasonlóképpen primitivista nézetet vallott, mint aztán a jósággal kapcsolatban, ${ }^{20}$ ugyanakkor a nyitott kérdés argumentumot sosem alkalmazta az igazság definiálhatatlanságának bizonyítására. A következő (4.1.) szakaszban röviden vázolom Moore nyitott kérdés argumentumát, amellyel a jó definiálhatatlansága mellett foglal állást, ezt követően (4.2.) pedig megvizsgálom, hogy alkalmazható-e Moore érve az igazsággal kapcsolatban.

\subsection{A nyitott kérdés argumentum}

Moore érvének rekonstrukciójához induljunk ki a következő, igencsak plauzibilis feltételezésből: a világban vannak összetett és egyszerủ tárgyak. Az összetett tárgyakat azáltal ismerhetjük meg, hogy analizáljuk, avagy elemeire bontjuk őket, mindaddig haladva, amíg nem jutunk el az összetett tárgyak egyszerű alkotóelemeihez. Moore szerint az egyszerü és az összetett tárgyak analógiájára gondoljuk el, hogy vannak összetett és egyszerű fogalmak is. Moore az egyszerủ fogalom példáját a következőképp illusztrálja:

Nézetem szerint a ,jó” ugyanúgy egyszerü fogalom, ahogy a „sárga” is egyszerủ fogalom, és ugyanúgy, ahogy annak, aki eleve nem tudja, hogy mi a sárga, semmiféleképpen sem tudjuk megmagyarázni ezt, nem tudjuk megmagyarázni azt sem, hogy mi a jó. ${ }^{21}$

Az összetett fogalmakat a ló definiálásának példáján keresztül mutatja be. Moore a következőképp definiálja a lovat: „A lófélék családjába tartozó, négylábú patás állat.”22 Látható, hogy a „négylábú”, „patás”, „állat”, „lófélék családjába tartozó” szavak által kifejezett fogalmak segítségével definiáljuk a lovat. Ebben áll a ló fogalmának összetettsége.

Egy ló definícióját azért tudjuk megadni, mert a lónak számos eltérő tulajdonsága és sajátossága van, amelyek mind felsorolhatók. De amikor már minden tulajdonságot felsoroltunk, amikor a lovat visszavezettük legegyszerủbb elemeire, akkor ezeket az elemeket már nem tudjuk definiálni. ${ }^{23}$

Moore szerint tehát az egyszerű dolgok, vagy inkább - összehangolva az eddigi gondolatmenettel - tulajdonságok közé tartozik a jó, amely redukálhatatlan, analizálha-

20 Moore 1993b, 20-22.

21 Moore 1981, 60.

22 Moore 1981, 61.

23 Moore 1981, 60. 
tatlan, azaz fogalmilag és metafizikailag egyszerű, amelyet nem tudunk más, a jónál alapvetőbb fogalmakkal magyarázni. ${ }^{24}$

Fontos tisztázni, hogy Moore milyen értelemben akarja definiálni a jót. Moore különbséget tesz verbális definíció és reális definíció között, és egyértelműen hangsúlyozza, hogy nem a „jó" szó használata érdekli, hanem a jó reális definíciója, vagyis az, hogy definiálható-e a jó természete.

Hogyan kell a jót definiálnunk? Azt gondolhatnánk, hogy ez pusztán verbális kérdés. Gyakran egy definíció valóban azt jelenti, hogy egy szó jelentését más szavakkal fejezzük ki. De én nem ilyesféle definíciót keresek. Az ilyen definíció a lexikográfiát kivéve semmilyen más tudományban nem lehet alapvetỏen fontos. Ha ilyen típusú definíciót akarnék, akkor mindenekelőtt azt kellene megfigyelnem, hogy az emberek általában miként használják a ,jó” szót; de nem rám tartozik a szónak a szokás által kialakított használata. [...] Nekem csak azzal a tárggyal vagy ideával van dolgom, amelynek a megjelölésére - véleményem szerint - általában a kérdéses szót használjuk. Én ennek a tárgynak vagy ideának a természetét akarom feltárni $[\ldots] . .^{25}$

Miután tisztázta, hogy milyen értelemben keresi a jó definícióját, a következőképp fogalmaz: „Arra a kérdésre, hogy »Mi a jó?«, azt válaszolom, hogy a jó az jó, és ezzel be is fejeztem. Vagy a »Hogyan definiálható a jó?« kérdésre a válaszom az, hogy a jót nem lehet definiálni." ${ }^{26}$

Nézzük most a fenti nyitott kérdés érv rekonstrukcióját. Tételezzük fel, hogy a jó definíció szerint $F$ (mondjuk, élvezetes vagy kellemes). Ha definíció szerint a jó valóban az $F$, akkor a ,jó-e az, ami $F$ ?” kérdés, vagy az „ami $F$ az nem jó” kijelentés nem lehet értelmes. Márpedig nagyon úgy néz ki, hogy bármit is helyettesítünk az $F$ helyére anélkül, hogy körben forgó lenne -, értelmesen feltehető a ,jó-e az, ami F?” kérdés vagy értelmesen állíthatjuk, hogy „az, ami $F$ nem jó”. Mivel Moore szerint a jó valamennyi definíciójának esetében mindig értelmesen feltehető a kérdés, hogy a jó-e az a valami (leginkább cselekvések vagy személyek jöhetnek szóba), amely rendelkezik azzal az $F$ tulajdonsággal, amellyel rendelkezni szükséges és elégséges feltétele annak, hogy a kérdéses dolog jó legyen, ebből következően a jó nem lehet definíció szerint $F$. Nézzük mindezt áttekinthetőbb megfogalmazásban:

P1 Definíció szerint a jó az $F$.

24 A nyitott kérdés argumentumot alaposan vizsgálja: Bács 2003, 117-121; Paár 2012, 107-121; Ambrus 2014, 25-45.

25 Moore 1981, 58-59.

26 Moore 1981, 59. 
P2 Ha definíció szerint a jó az $F$, akkor nem értelmes az a kérdés, hogy: „valóban jó-e az, ami $F$ ?"

P3 De értelmes az a kérdés, hogy: „valóban jó-e az, ami F?”

K: (P2-ből és P3-ból) Nem igaz az, hogy a jó az F.

Asay javaslata alapján a nyitott kérdés érv alkalmazásának három következménye lehet. ${ }^{27} \mathrm{Az}$ érv akkor sikeres, ha (1) a kérdés, hogy vajon a jó $F$-e, nyitott marad, ahogy fentebb is értelmesen feltehetjük a kérdést, hogy például az, ami élvezetes, valóban jó-e. Továbbá akkor is sikeres, ha (2) zárt az előző kérdés, mégpedig úgy, hogy a definíció triviális, semmitmondó például a jó azonos a jóval. Végül pedig, az érv csak akkor mond csődöt, tehát a kérdéses fogalom definiálhatatlansága akkor nem igazolódik be, ha (3) a kérdés zárt, mégpedig úgy, hogy helyes, informatív definíciót kapunk. Amennyiben az első eset következik be, úgy világos, hogy az $F$ helyére behelyettesített fogalom nem megfelelő jelölt arra, hogy a jó definíciójában felhasználhassuk, mert nyitva hagyja azt a kérdést, hogy „valóban jó-e az élvezet?”. Márpedig Moore szerint egy definíció, jelen esetben a jó definíciója a jó valódi természetének feltárására született, mégpedig a fogalmi analízisen keresztül. Ám ha a jó és az élvezet fogalmai azonosak, akkor fel sem merülhetne az a kérdés, hogy az élvezet jó-e. A második eset nyilvánvalóan nem vezet eredményre, hiszen az a meghatározás, amelyben a definiendum ugyanaz, mint a definiens csak tautologikus lehet, márpedig egy definíciótól azt várnánk, hogy általa megtudhatunk valami újat a definiendumról, jelen esetben a jóról. Egyedül (3) kínálhat megoldást, azonban nagyon úgy tűnik, legalábbis Moore szerint, hogy a jó definiálási kísérletei során nem tudunk az $F$ helyére olyan fogalma(ka)t behelyettesíteni, ami által kielégítő definíciót kaphatnánk. A következő szakaszban a nyitott kérdés érvet alkalmazom az igazság 2. szakaszban említett definíciójára, és amellett érvelek, hogy ezek a szubsztantivista kísérletek nem képesek kielégítően definiálni az igazságot.

\subsection{A nyitott kérdés argumentum alkalmazhatósága az igazságra}

A továbbiakban úgy rekonstruálom Moore érvét, hogy a jó helyett az igazság definiálhatatlanságának bizonyítását célozza. ${ }^{28}$ Ehhez a fentebb vázolt érvet átalakítom az igazság koherencia elméletének 2. szakaszban bevezetett (KohT) definíciójára:

P1 Definíció szerint $p$ akkor és csak akkor igaz, ha $p$ eleme egy koherens kijelentéshalmaznak.

27 Asay 2013, 177.

28 Hasonlóan jár el Savery 1955 és Asay 2013, 175-185. 
P2 Ha definíció szerint $p$ akkor és csak akkor igaz, ha $p$ eleme egy koherens kijelentéshalmaznak, akkor nem lehet értelmes kérdés az, hogy: „valóban igaz $p$, ha egy koherens kijelentéshalmaz eleme?”

P3 De értelmes az a kérdés, hogy „valóban igaz $p$, ha egy koherens kijelentéshalmaz eleme?" 29

K: (P2-ből és P3-ból) Nem igaz, hogy az igazság az, hogy p eleme egy koherens kijelentéshalmaznak.

Ugyanezt érvényesen felírhatnánk a pragmatista elmélet által kínált definícióra, vagyis (PragT)-re is. Azonban úgy tűnik, hogy a korrespondenciaelmélet definíciója (KorrT) pozitíve zárttá teszi a kérdést, ugyanis értelmes azt mondani, hogy „koherens, de nem igaz”, vagy „hasznos, de nem igaz”, viszont az nem tünik értelmesnek, hogy „megfelel a tényeknek, de nem igaz”. Azonban a korrespondenciaelmélet által kínált definícióval kapcsolatban azt is felvethetnénk, hogy a korrespondenciaelmélet által kínált definíció nem több egy semmitmondó állításnál, vagyis az, hogy $p$ igaz és az, hogy $p$ megfelel a tényeknek ugyanazt mondja. Egy szimpla parafrázis, ami alapján nem tudunk meg semmit az igazságról. Mondhatnánk azt is, hogy a következő mondat tautologikus: „igaz az, ami megfelel a tényeknek”. A kérdés ugyan zárt lesz, de egyben semmitmondó is, következésképp az analízis ez esetben is elhibázott. ${ }^{30}$

Moore érvével kapcsolatban azonban van egy komolyabb probléma, amivel mindenképp számot kell vetnünk. Moore nem számol azzal, hogy különbözö jelentésü fogalmak referálhatnak egy és ugyanazon tulajdonságra. Frege ezt számításba veszi, az ide vonatkozó passzusa így szól:

Kézenfekvő tehát, hogy egy jellel (névvel, szókapcsolattal, írásjeggyel) ne csak azt kapcsoljuk össze, amit megjelöl, s amit a jel jelöletének hívhatunk, hanem ezenkívül azt is, amit a jel jelentésének neveznék, és amely a meghatározás módját foglalja magában. Így példánkban az „, $a$ és $b$ metszéspontja”, valamint a „ $b$ és $c$ metszéspontja” kifejezések jelölete ugyan megegyezik, jelentésük azonban nem. Az „Alkonycsillag” és a „Hajnalcsillag” jelölete azonos, jelentésük azonban nem. ${ }^{31}$

Frege ismert példája arra hívja fel a figyelmünket, hogy vannak bizonyos kifejezések, amelyek jelentésükben különböznek, ugyanakkor mindkét kifejezés egyazon dologra referál.

29 Igen jó érvek hozhatók fel amellett, hogy önmagában egy propozíció- vagy kijelentéshalmaz koherenciája még nem elégséges a halmazhoz tartozó propozíciók vagy kijelentések igazságához. Ezen érvekhez lásd Russell 1907, Schlick 1999, illetve Kocsis 2018, 56-60.

30 Terjedelmi korlátok miatt ezen állítás alátámasztására nem teszek kísérletet, de hasonlót állít Blackburn 1984, 224-226 és Ramsey 2018, 141-151.

31 Frege 2000, 120. (Saját kiemelés.) 
Frege pontos példáját elvetve, de lényegét megtartva a „víz” és a „ $\mathrm{H}_{2} \mathrm{O}$ ” kifejezéseket, illetve az általuk kifejezett fogalmakat alkalmazom a példámban, hogy érthetőbben tudjam szemléltetni a különbséget. Világos, hogy a „víz” és a „ $\mathrm{H}_{2} \mathrm{O}$ ” szavak két különböző fogalmat fejeznek ki, annak ellenére, hogy ugyanazt a dolgot jelölik. Vannak olyan esetek, amikor valaki rendelkezik a víz fogalmával anélkül, hogy rendelkezne a $\mathrm{H}_{2} \mathrm{O}$ fogalmával. Gondoljuk egy kisgyerekre, aki még nem rendelkezik a $\mathrm{H}_{2} \mathrm{O}$ fogalmával, de ha kérünk tőle egy pohár vizet, akkor tudja, hogy mit kérünk tőle. Rendelkezhet valaki a víz fogalmával, annak ellenére, hogy nem rendelkezik a $\mathrm{H}_{2} \mathrm{O}$ fogalmával, vagyis nem tudja, hogy a víz azonos a dihidrogén-monoxiddal.

Ha Moore érvét akarnánk támadni, akkor azt kellene megmutatnunk, hogy Moore nem számol azzal, hogy különböző jelentésủ fogalmaknak lehet azonos a referenciájuk. Vagy ha úgy tetszik: egy szemantikai premisszából metafizikai konklúziót von le. A jó esetében elképzelhető, hogy a „jó” és az „élvezet” vagy a „jó” és a „kellemes” különböző jelentésekkel bírnak, de mégis ugyanazon tulajdonságra referálnak. Ahogy a „víz” és a „ $\mathrm{H}_{2} \mathrm{O}$ ” vagy az „Alkonycsillag” és „Hajnalcsillag” nevek esetében is kiderült, hogy a különböző jelentések ellenére ugyanazon dologra referálnak, ugyanígy elképzelhető, hogy kiderül a jó valóban azonos az élvezettel vagy a kellemességgel, vagyis a „jó” és az „élvezetes”, ahogy a „víz” és a „ $\mathrm{H}_{2} \mathrm{O}$ ” ugyanazon tulajdonságra referálnak.

Moore leszögezi ugyan, hogy őt nem a jó jelentése érdekli, azonban amikor érvel, mégis a jelentés különbözöségéböl következtet a tulajdonságok különbözöségére, miközben könnyen megeshet, hogy nem tulajdonságokról kell beszélni, hanem egy tulajdonságról, amelyre két különböző jelentésű kifejezés és az általuk kifejezett két különböző fogalom is referálhat. Az érvet megpróbálom úgy alkalmazni, hogy annak segítségével a víz definícióját keressük, és ezt a $\mathrm{H}_{2} \mathrm{O}$-val próbáljuk megadni. Eszerint így fest az érv:

P1 Definíció szerint a víz az $\mathrm{H}_{2} \mathrm{O}$.

P2 Ha definíció szerint a víz az $\mathrm{H}_{2} \mathrm{O}$, akkor nem értelmes az a kérdés, hogy: „valóban víz-e az, ami $\mathrm{H}_{2} \mathrm{O}$ ?"

P3 De értelmes az a kérdés, hogy: „valóban víz-e az, ami $\mathrm{H}_{2} \mathrm{O}$ ?”

K: (P2-ből és P3-ból) Nem igaz az, hogy a víz az $\mathrm{H}_{2} \mathrm{O}$.

Bár Moore érve - úgy tűnik - működik a jóra és az igazságra vonatkozóan, de a vízzel kapcsolatban nem állja meg a helyét, ugyanis ez tökéletesen ellenkezik az eddigi ismeretünkkel, amely a kémia azon megállapításán nyugszik, hogy a víz azonos a $\mathrm{H}_{2} \mathrm{O}$-val. Mivel a víz empirikusan tisztázható fogalom, a kémia fejlődésének köszönhetően manapság egy kifinomult vízfogalommal rendelkezünk, még ha vannak is olyanok, akik nincsenek tisztában azzal, hogy a víz nem más, mint $\mathrm{H}_{2} \mathrm{O}$. Úgy tünik azonban, hogy az 
igazság (ahogy a jóság) fogalma nem tisztázható empirikus vizsgálódások segítségével. E fogalmak elemzésénél kizárólag a fogalmi elemzés a priori módszerére hagyatkozhatunk.

Jó indokkal feltételezzük, hogy az igazsággal kapcsolatos vizsgálódások kizárólag fogalmi jellegűek lehetnek. Éppen ezért a fogalmi eltérések, amelyre a nyitott kérdés argumentum segítségével az igazsággal kapcsolatban felhívtuk a figyelmet, elegendő alapul szolgálhatnak arra, hogy a tulajdonság szintjén is különbséget tegyünk, mert másképp nem tudunk hozzáférni a tulajdonság (jelen esetben: az igazság) természetének pontos meghatározásához, kizárólag a fogalom elemzésén keresztül. Ha az igazság fogalma és egy kijelentés más kijelentésekkel való koherenciában állás fogalma (vagy éppen a hasznosság fogalma) eltérnek egymástól, akkor jó indokkal feltételezzük, hogy az igazság és a koherens kijelentéshalmaz elemének levés (vagy a hasznos benne hinni) tulajdonságai sem lehetnek azonos tulajdonságok. A korrespondenciaelmélet esetében pedig, még egyszer, azzal lehet érvelni, hogy az igazság és a tényeknek való megfelelés fogalmi szinten sem különböznek.

\section{Konklúzió}

Tanulmányomban arra tettem kísérletet, hogy megvizsgáljak két érvet, amelyek egyaránt az igazság definiálhatatlansága mellett szólnak. Frege érve szerint, amikor az igazság definiálására teszünk kísérletet, akkor szükségképpen a végtelen regresszus vagy a körkörösség csapdájába esünk; a mindenütt jelenvalósági tézis szerint pedig az igaznak tartás minden állításunk szükségszerű velejárója, tehát az ,igaz” szó kimondása - amenynyiben grammatikailag nem szükséges - nélkülözhető, ebből következően pedig semmi esetre sem tekinthetünk az igazságra úgy, mint amelyről egy szubsztantív, robosztus elmélet keretében számot lehetne adni. Igyekeztem továbbá rámutatni, hogy bár a regresszus/körkörösségi érv, valamint a mindenütt jelenvalóság tézise függetlenek egymástól, ennek ellenére a mindenütt jelenvalóság tézise támogatja a regresszus/körkörösségi érvet.

Fregével ellentétben Moore eredeti érve nem az igazság, hanem a jó fogalmát érinti. Az eredeti érv rekonstrukcióját követően arra a kérdésre kerestem választ, hogy Moore nyitott kérdés argumentuma alkalmazható-e az igazságra. Arra a konklúzióra jutottam, hogy Frege mellett Moore érve is azt igazolja, hogy az igazság fogalma speciális abban az értelemben, hogy a ráirányuló definíciós kísérletek nem lehetnek sikeresek. Ez jól megmutatható a koherentista és pragmatista igazságelméletek esetében, ám a korrespondenciaelmélet definíciója már kétségeket ébreszthet bennünk a nyitott kérdés argumentum használhatóságát illetően. Azonban jó indokaink lehetnek, hogy a korrespondenciael- 
mélet definícióját ne tartsuk informatívnak arra vonatkozóan, hogy mi az igazság természete. Inkább azt mondhatnánk, hogy pusztán parafrazeálja azt, hogy mikor igaz egy kijelentés. Továbbá annak kimutatására tettem kísérletet, hogy Moore érve akkor igazán hatásos, amikor nem áll módunkban a priori fogalmi elemzéstől eltérő vizsgálódás segítségével tisztázni bizonyos fogalmakat.

\section{Bibliográfia}

Ambrus Gergely. 2014. „Moore nyitott kérdés érve: a Principia Ethica kontextusban.” Magyar Filozófiai Szemle 58/3: 25-45.

Asay, Jamin. 2013. The Primitivist Theory of Truth. Cambridge: Cambridge University Press. DOI: $10.1017 / \mathrm{CBO} 9781139856003$.

Asay, Jamin. 2014. „Primitive Truth.” Dialectica 67/4: 503-19. DOI: 10.1111/1746-8361.12041.

Bács Gábor. 2003. „Jó-e a nyitott kérdés érv?” Világosság 44/5-6: 117-21.

Blackburn, Simon. 1984. Spreading the Word. Oxford: Clarendon Press.

Davidson, Donald. 1996. „The Folly of Trying to Define Truth.” The Journal of Philosophy 93/6: 263-78. DOI: 10.2307/2941075.

Dummett, Michael. 1973. „Can Truth be Defined?” In Frege: Philosophy of Language, 442-70. London: Harper \& Row Publishers.

Frege, Gottlob. 2000. „A gondolat.” Ford. Máté András. In Logikai vizsgálódások, 191-217. Budapest: Osiris.

Frege, Gottlob. 2000. „Jelentés és jelölet.” Ford. Máté András. In Logikai vizsgálódások, 118-48. Budapest: Osiris.

Jackson, Frank. 2000. From Metaphysics to Ethics: A Defence of Conceptual Analysis. Oxford: Oxford University Press. DOI: 10.1093/0198250614.001.0001.

Kant, Immanuel. 2009. A tiszta ész kritikája. Ford. Kis János - Papp Zoltán. Budapest: Atlantisz. Kocsis László. 2018. „Bevezetés az igazságelméletekbe.” In Az igazság elméletei, szerk. Kocsis László, 13-129. Budapest: L'Harmattan.

Márton Miklós. 2010. „A fogalmi elemzés oxfordi filozófiájáról.” Világosság 51/1: 43-57.

Moore, George E. 1981. „Principia Ethica.” Ford. Lónyai Mária - Takács Ferenc. In Tények és értékek, szerk. Lónyai Mária, 51-105. Budapest, Gondolat.

Moore, George E. 1993a. „The Nature of Judgment.” In G. E. Moore: Selected Writings, szerk. Thomas Baldwin, 1-19. London: Routledge.

Moore, George E. 1993b. „Truth and Falsity.” In G. E. Moore: Selected Writings, szerk. Thomas Baldwin, 20-22. London: Routledge.

Paár Tamás. 2012. „Mire jó a nyitott kérdés argumentum?” Elpis 6/1: 107-21.

Patterson, Douglas. 2010. „Truth as Conceptually Primitive.” In New Waves in Truth, szerk. C. D. Wright - N. J. L. L. Pedersen, 13-29. Basingstoke: Palgrave Macmillan. 
Ramsey, Frank. 2018. „Az igazság természete.” Ford. Kocsis László. In Az igazság elméletei, szerk. Kocsis László, 141-51. Budapest: L’Harmattan.

Russell, Bertrand. 1904. „Meinong's Theory of Complexes and Assumptions (III.).” Mind 13/52: 509-24. DOI: $10.1093 / \mathrm{mind} /$ xiii.1.509.

Russell, Bertrand. 1907. „On the Nature of Truth.” Proceedings of the Aristotelian Society 7/1: 228-49. DOI: 10.1093/aristotelian/7.1.28.

Savery, Barnett. 1955. „The Emotive Theory of Truth.” Mind 64: 513-21. DOI: 10.1093/mind/ LXIV.256.513.

Schlick, Moritz. 1999. „Az ismeret fundamentumáról.” Ford. Fehér Márta. In Tudományfilozófia, szerk. Forrai Gábor - Szegedi Péter, 27-40. Budapest: Áron.

Soames, Scott. 1999. Understanding Truth. Oxford: Oxford University Press. DOI: 10.1093/0195123352.001.0001.

Sosa, Ernest. 2001. „Epistemology and Primitive Truth.” In The Nature of Truth, szerk. M. P. Lynch, 641-62. Cambridge, MA: MIT Press.

Stepanians, Markus. 2003. „Why Frege thought it to be »Probable« that Truth is Indefinable.” Manuscrito 26/2: 331-45.

Strawson, Peter. 1992. Analysis and Metaphysics: An Introduction to Philosophy. Oxford: Oxford University Press. DOI: 10.1093/acprof:oso/9780198751182.001.0001. 